\title{
The Australian DREEM: evaluating student perceptions of academic learning environments within eight health science courses
}

\author{
Ted Brown', Brett Williams², Marty Lynch'1 \\ ${ }^{1}$ Department of Occupational Therapy, Faculty of Medicine, Nursing, and Health Sciences, Monash University, Australia \\ ${ }^{2}$ Department of Community Emergency Health and Paramedic Practice, Faculty of Medicine, Nursing, and Health Sciences, \\ Monash University, Australia
}

Correspondence: Ted Brown, Department of Occupational Therapy, Faculty of Medicine, Nursing, and Health Sciences, Monash University - Peninsula Campus, Building, $4^{\text {th }}$ Floor, PO Box 527, Frankston, Victoria, 3199, Australia

Email: ted.brown@monash.edu

Accepted: September 06, 2011

\begin{abstract}
Objectives: The purpose of this cross sectional study is to investigate student perceptions of learning environments at a major Australian University. Various aspects of environment are compared between courses, year levels, educational backgrounds and gender.

Methods: The Dundee Ready Education Environment Measure (DREEM) and a demographic questionnaire were completed by 548 undergraduate students enrolled in the emergency health, midwifery, radiography and medical imaging, occupational therapy, pharmacy, nutrition and dietetics, physiotherapy and social work courses at Monash University. Convenience sampling was used and scores were compared across grouping variables identified via demographic information.

Results: Scores across the sample were fairly high $(\mathrm{M}=$ 137.3; $\mathrm{SD}=18.3$ ), indicating an overall positive perception of learning environments among students. Total scores were significantly higher for females $(M=138.8$; $S D=17.2)$
\end{abstract}

than males $\left(\mathrm{M}=132.3 ; \mathrm{SD}=20.7 ; \mathrm{t}_{(545)}=3.51 ; \mathrm{p}=0.002\right)$ and this trend was consistent across all aspects of perceived learning environment (although not always significant). Students who enrolled in their course directly after completing high school yielded less positive ratings on some DREEM subscales than students who did not enrol immediately after completing high school.

Conclusions: The positive perception held by Monash University health science students towards their education and learning environments is hopefully indicative of similar courses within Australia and internationally. While future studies may help confirm this, the current findings offer a chance to explore the underlying causes of this positivity in more depth as well as compare similarities and differences between the specific health science disciplines.

Keywords: Health science students, learning environments, university, education, DREEM

\section{Introduction}

Each year thousands of health science professionals graduate from Australian tertiary institutions, many of whom are then employed as nurses, paramedics, midwives or one of a number of other health care disciplines. As these students enter their respective professions, their level of competence is not only a reflection of the educational institution they attended; it is of the utmost importance to all their future patients and the broader community generally. An im-

portant component of academic strengthening and curricula renewal is the evaluation of the quality and structure of health science programs. After all, it has been suggested that a positive learning environment as a student can lead to increased satisfaction, achievement and success as a practitioner post-graduation. ${ }^{1,2}$

As is the case with medicine ${ }^{3}$, the context of health science education has moved in recent decades to embrace a 
more student-centred curriculum., ${ }^{4,5}$ Fieldwork is now viewed as a vital part of the education of Australian health science students and is a professional requirement for course accreditation by most professional bodies. ${ }^{6,7}$ Students are therefore exposed to a combination of traditional classroom-based teaching, practical skills workshops and clinical fieldwork or practice education placements.

While a combination of classroom and clinical learning environments is commonplace within Australian health science courses, there is a scarcity of empirical evidence that defines or evaluates this current balance or the way its delivery is perceived by its students. Notwithstanding a scattering of efforts to evaluate specific aspects of curricula or techniques within certain courses, such as the impact of problem-based learning for medical, midwifery and paramedic students, ${ }^{8}$ the lack of broader empirical research means that little is known about the way health science students perceive their course learning environments. As a result, the opportunity to substantiate or 'fine tune' the current curriculum may have been overlooked to date.

The medical profession, largely through the Dundee Ready Education Environment Measure (DREEM), ${ }^{9}$ has been able to apply a much greater degree of empirical introspection when it comes to the learning environments of its students. The DREEM was originally used to evaluate the learning environments of medical students, whose course curriculum had rapidly changed during a period of major reforms in traditional teaching methods up until and during the 1990s; particularly a trend towards a more student-centred curriculum. ${ }^{9}$ A Delphi technique, involving a panel of 30 faculty members from around the world, was used to generate criteria indicative of desirable education climates for health professions in light of the new curriculum standards. The DREEM was then refined into 50-item self-report questionnaire using a 5-point Likert scale, with scores reflecting a student's overall perception of the environment as well as their perceptions of 5 main aspects of this environment, namely: their learning, the teachers, academic self-perception, atmosphere, and social selfperception.

By 2005 the DREEM ${ }^{10}$ had been used in studies in dozens of countries across Europe, Asia, Africa, North America, South America, and the Middle East and has since been applied in many other countries. ${ }^{11}$ In the process, many of these studies have been able to achieve a number of goals, including the generation of a profile of an institution's/course's strengths and weaknesses, making a comparative analysis within their institution or benchmarking between themselves and another institution and test and apply it as a predictor of student performance. ${ }^{10}$

Given the potential usefulness of the DREEM, not only to the institution that utilises it, but to other institutions that can use it as a reference point and the broader international community, it is regretful that the use of such a tool has not been more widespread across Australian health science courses. Even internationally, notwithstanding a handful of occasions where the DREEM has been employed with disciplines such as Nursing, ${ }^{10}$ Dentistry $^{12}$ and Chiropractic, ${ }^{2,13}$ the vast majority of major studies that have employed the DREEM have focussed on medical students. ${ }^{10}$ Within Australia, a single study that has applied the DREEM to any of the health sciences could not be located.

The DREEM appears to be very much applicable to the health science setting. Firstly, there is something generic about the inventory's items. Not only do several DREEM items appear in other inventories related to the evaluation of education, ${ }^{14}$ but the findings from the DREEM have been found to be consistent with qualitative information attained via interviews. ${ }^{11}$ Secondly, even though the DREEM has been used mainly for medical students, it was constructed by a panel of faculty from health profession generally and items were constructed based on their perceptions of learning climates conducive to education in the health professions, not just medicine. $^{9}$

Applying the DREEM to a range of Australian health science students would be invaluable on a range of levels. Firstly it would provide an insightful snapshot of the way these students view their respective courses and enable the institution to address any key issues, just as several medical institutions have done previously. ${ }^{2,11,15,16}$ This would have a positive impact on the training and therefore the industry and service provided to the broader Australian health care sector. Secondly, many of these findings may infer parallel trends for other Australian or international institutions that run one or more similar courses. Alternatively, the findings from such a study might be a useful point of reference for future DREEM studies that involve health science students. Finally, if administered in conjunction with the collection of demographic information, this would allow for exploration of trends such as those found previously between course types, ${ }^{10,12}$ year level ${ }^{2,13}$ and gender, ${ }^{15-17}$ as well as other variables; adding a greater depth of information for both the university and the broader health science training community.

Therefore, the aim of this study is to evaluate, by way of student perceptions recorded on the DREEM inventory, the overall education environment within health science courses that employ a balance of traditional classroombased teaching and clinical fieldwork, as well as specific aspects of this learning environment. A second aim of this study is to investigate whether the education environment or aspects of it are perceived more or less favourably for students of difference health professions, year levels, educational backgrounds or gender.

\section{Methods}

\section{Participants}

A cross-sectional survey design using a standardised selfreport scale was conducted. Participants included 548 
students (response rate 55\%) enrolled in undergraduate health science programs offered at Monash University, Victoria, Australia in 2008-2009, whose courses consisted of traditional classes and clinical fieldwork. This comprised of students from bachelor degrees in Occupational Therapy (76), Physiotherapy (33), Emergency Health (60), Midwifery (37), Nutrition and Dietetics (31), Pharmacy (116), Social Work (78) and Radiography and Medical Imaging (114). Courses are four years in length with the exception of Midwifery and Emergency Health (three years) and Social Work (two years of Social Work courses plus two years of related studies). Three participants failed to indicate their course.

These courses represented virtually all major health science courses offered at Monash University. Nursing students were excluded from the study since another university researcher was investigating other practice education issues with this group. Medicine students, who are administered from a different school within the faculty, were not included for practical reasons. Convenience sampling was used to source participants from each discipline. Inclusion criteria for student participants were, a) being enrolled at Monash University in a health science program, b) able to provide consent to take part in the study, and c) having a working knowledge of the English language.

\section{Instrument}

A short demographic questionnaire was constructed to collect information such as the participant's gender, age group, and course.

DREEM is a 50 -item self-report questionnaire designed to assess students' perspectives of the educational environment within health professional and medical schools. The DREEM is a validated and reliable inventory ${ }^{9,18}$ and has been used in many studies of health care education throughout the world. ${ }^{10}$ High internal consistency has been reported independently by Cronbach alpha levels of 0.92 and 0.93 respectively.

Items are in the form of statements relating to the respondent's course environment (e.g., "I am encouraged to participate in class"), which are rated via 5-point Likert scale, where $4=$ strongly agree and $0=$ strongly disagree. Nine items are worded negatively (e.g., "Cheating is a problem in this school") and are reversed scored by the researcher before tallying. Item scores count towards an overall environment score as well as one of five subscales or domains (abbreviations and maximum subscale scores are in parenthesis): Students' Perceptions of Learning (SPL, 48), Students' Perceptions of Teaching (SPT, 44), Students' Academic Self-perception (SAP, 32), Students' Perception of Atmosphere (SPA, 48) and Students' Social Selfperception (SSP, 28).

The overall DREEM score is out of 200. As such, previous studies ${ }^{17}$ have used the following as an approximate guide to interpreting the overall scores: 0-50 (0-25\%) = very poor; $51-100(25.1-50 \%)=$ plenty of problems; $101-150$ $(50.1-75 \%)=$ more positive than negative; 151-200 (75.1$100 \%)=$ excellent. The ranges shown in brackets allow mean scores to be displayed as a percentage of the maximum possible score. In the past, this has also enabled interpretation and comparison of mean scores for the five subscales, which each have a different total score..$^{15,16,20}$

Table 1. Demographic information of participants sampled from Monash University health science students in 2008/9 ( $=548)$

\begin{tabular}{|c|c|c|}
\hline Variable & \multirow{2}{*}{$\mathrm{N}$} & \multirow{2}{*}{$(\%)$} \\
\hline Gender & & \\
\hline Male & 127 & 23.2 \\
\hline Female & 421 & 76.8 \\
\hline \multicolumn{3}{|l|}{ Age } \\
\hline $15-19$ years & 124 & 22.6 \\
\hline 20-24 years & 342 & 62.4 \\
\hline $25-29$ years & 38 & 6.9 \\
\hline $30-34$ years & 10 & 1.8 \\
\hline $35-39$ years & 18 & 3.3 \\
\hline 40 years or older & 16 & 2.9 \\
\hline \multicolumn{3}{|c|}{ Number of students from each health science course } \\
\hline Occupational Therapy & 76 & 13.9 \\
\hline Physiotherapy & 33 & 6.0 \\
\hline Emergency Health & 60 & 10.9 \\
\hline Midwifery & 37 & 6.8 \\
\hline Dietetics \& Nutrition & 31 & 5.7 \\
\hline Pharmacy & 116 & 21.2 \\
\hline Social Work & 78 & 14.2 \\
\hline Radiography \& Medical Imaging & 114 & 21.8 \\
\hline Course not indicated & 3 & 0.5 \\
\hline \multicolumn{3}{|l|}{ Year of enrolment } \\
\hline $1^{\text {st }}$ year & 121 & 22.2 \\
\hline $2^{\text {nd }}$ year & 101 & 18.5 \\
\hline $3^{\text {rd }}$ year & 150 & 27.5 \\
\hline $4^{\text {th }}$ year & 176 & 32.3 \\
\hline
\end{tabular}

\section{Procedures}

Ethics approval for the study was granted by the Monash University Standing Committee on Ethics in Research Involving Humans. Participants received an explanatory statement detailing the study and were informed that all data collected would be de-identified so that involvement remained anonymous. Participants' consent to take part in the study was inferred by their completion of the questionnaire. The DREEM and demographic information questionnaire were distributed to students in each health science program towards the end of a lecture, which itself recently followed completion of a fieldwork educational block. A non-teaching member of staff facilitated the process and collected the completed surveys. 
Table 2. Mean (SD) subscale and total DREEM scores for Monash University health science students in 2008/9 by health science discipline $(\mathrm{N}=545)$

\begin{tabular}{|c|c|c|c|c|c|c|c|c|c|c|c|c|}
\hline & OT & PT & $\mathrm{EH}$ & MW & DN & Phar & SW & $\mathrm{RMI}$ & All & $\mathrm{F}$ & $\mathrm{p}$ & Tukey's $<0.05$ \\
\hline SPL & $\begin{array}{l}33.3 \\
(4.9)\end{array}$ & $\begin{array}{l}33.6 \\
(5.1)\end{array}$ & $\begin{array}{l}34.0 \\
(4.5)\end{array}$ & $\begin{array}{l}33.3 \\
(5.7)\end{array}$ & $\begin{array}{l}35.1 \\
(4.9)\end{array}$ & $\begin{array}{l}30.9 \\
(5.5)\end{array}$ & $\begin{array}{l}32.8 \\
(5.4)\end{array}$ & $\begin{array}{l}32.9 \\
(5.6)\end{array}$ & $\begin{array}{l}32.8 \\
(5.4)\end{array}$ & 3.55 & 0.001 & EH-Phar, DN-Phar \\
\hline SPT & $\begin{array}{l}32.7 \\
(4.4)\end{array}$ & $\begin{array}{l}32.6 \\
(4.7)\end{array}$ & $\begin{array}{l}33.2 \\
(4.0)\end{array}$ & $\begin{array}{l}31.2 \\
(6.4)\end{array}$ & $\begin{array}{l}34.0 \\
(4.5)\end{array}$ & $\begin{array}{l}30.5 \\
(5.0)\end{array}$ & $\begin{array}{l}30.3 \\
(4.9)\end{array}$ & $\begin{array}{l}30.8 \\
(5.3)\end{array}$ & $\begin{array}{l}31.5 \\
(5.0)\end{array}$ & 4.59 & 0.000 & $\begin{array}{l}\text { EH-Phar, DN-Phar, EH- } \\
\text { SW, DN-SW, DN-RMI }\end{array}$ \\
\hline SAP & $\begin{array}{l}21.2 \\
(4.3)\end{array}$ & $\begin{array}{l}20.6 \\
(3.4)\end{array}$ & $\begin{array}{l}21.4 \\
(3.1)\end{array}$ & $\begin{array}{l}21.0 \\
(4.6)\end{array}$ & $\begin{array}{l}21.6 \\
(3.5)\end{array}$ & $\begin{array}{l}20.6 \\
(3.8)\end{array}$ & $\begin{array}{l}21.7 \\
(3.4)\end{array}$ & $\begin{array}{l}21.5 \\
(4.6)\end{array}$ & $\begin{array}{l}21.2 \\
(3.9)\end{array}$ & 0.85 & 0.547 & \\
\hline SPA & $\begin{array}{l}33.6 \\
(6.3)\end{array}$ & $\begin{array}{l}33.2 \\
(5.6)\end{array}$ & $\begin{array}{l}35.0 \\
(4.1)\end{array}$ & $\begin{array}{l}31.6 \\
(5.8)\end{array}$ & $\begin{array}{l}33.8 \\
(5.5)\end{array}$ & $\begin{array}{l}31.7 \\
(6.1)\end{array}$ & $\begin{array}{l}32.3 \\
(5.4)\end{array}$ & $\begin{array}{l}32.3 \\
(5.9)\end{array}$ & $\begin{array}{l}32.8 \\
(5.8)\end{array}$ & 2.63 & 0.011 & EH-Phar \\
\hline SSP & $\begin{array}{l}19.3 \\
(3.9)\end{array}$ & $\begin{array}{l}20.2 \\
(4.1)\end{array}$ & $\begin{array}{l}19.9 \\
(2.9)\end{array}$ & $\begin{array}{l}18.4 \\
(4.0)\end{array}$ & $\begin{array}{l}19.7 \\
(3.3)\end{array}$ & $\begin{array}{l}19.2 \\
(3.2)\end{array}$ & $\begin{array}{l}18.1 \\
(4.0)\end{array}$ & $\begin{array}{l}18.4 \\
(3.5)\end{array}$ & $\begin{array}{l}19.0 \\
(3.6)\end{array}$ & 2.55 & 0.014 & \\
\hline $\begin{array}{l}\text { Total } \\
\text { DREEM }\end{array}$ & $\begin{array}{l}140.0 \\
(19.0)\end{array}$ & $\begin{array}{l}140.6 \\
(19.2)\end{array}$ & $\begin{array}{l}143.4 \\
(10.8)\end{array}$ & $\begin{array}{l}135.5 \\
(21.7)\end{array}$ & $\begin{array}{l}145.5 \\
(17.8)\end{array}$ & $\begin{array}{l}133.0 \\
(18.9)\end{array}$ & $\begin{array}{l}135.4 \\
(15.1)\end{array}$ & $\begin{array}{l}135.6 \\
(19.5)\end{array}$ & $\begin{array}{l}137.3 \\
(18.3)\end{array}$ & 3.50 & 0.001 & EH-Phar, DN-Phar \\
\hline $\mathrm{n}$ & 76 & 33 & 60 & 37 & 31 & 116 & 78 & 114 & 545 & & & \\
\hline
\end{tabular}

SPL, Students' Perceptions of Learning; SPT, Students' Perceptions of Teaching; Students' Academic Self-perception; SPA, Students' Perception of Atmosphere; SPT, Students' Social Self-perception; OT, Occupational Therapy, PT, Physiotherapy; EH, Emergency Health; MW, Midwifery; Phar, Pharmacy; DN, Dietetics \& Nutrition; SW, Social Work; RMI, Radiography and Medical Imaging.

\section{Statistical Analysis}

DREEM scores and demographic data were entered into Statistical Package for the Social Sciences (SPSS) Version 18.0. Means and standard deviations were calculated for DREEM total and subscale scores for the entire sample as well as for specific course cohorts and other subgroups identified by the demographic data collected.

For dichotomous variables (gender and educational background) comparisons of total and subscale DREEM score means were carried out using a series of independent measures t-tests. For variables with more than two factors (health science course and year level), a series of one-way Analyses of Variance (ANOVAs) were used to compare all groups. Where the ANOVA indicated a significant difference among groups, Tukey's HSD (adjusted for multiple comparisons) was used to make post hoc pair-wise comparisons for that scale. Significant pair-wise differences $(\mathrm{p}<0.05)$ are reported.

\section{Results}

\section{Participant demographics}

Table 1 shows the number and percentage of participants by gender, age group, course and year-level of enrolment. In addition to these figures it was noted that almost all participants (96.9\%) had completed their high school/college certificate (in Australia alternative admission requirements are often extended to, for example, mature-aged students) and the majority enrolled in their course directly from high school (58.17\%).

\section{DREEM scores between health science courses}

The mean total DREEM score was 137.3 (68.7\% of the maximum score) and standard deviation was 18.3 . Subscale means and standard deviations for the entire sample as well as each course are displayed in Table 2.

Where applicable, post hoc analyses that yielded significant differences between pairs of courses are also indicated. Total DREEM scores varied significantly between courses $\left(\mathrm{F}_{(7,525)}=3.50 ; \mathrm{p}<.001\right)$. Post hoc analyses indicted that Emergency Health students and Dietetics and Nutrition students yielded significantly higher total DREEM scores than Pharmacy students.

SPL scores varied significantly between courses $\left(\mathrm{F}_{(7,532)}=\right.$ $3.55 ; \mathrm{p}=0.001)$. Post hoc analyses indicated that Emergency Health students and Dietetics and Nutrition students also gave significantly higher SPL scores than Pharmacy students.

SPT scores varied significantly between courses $\left(\mathrm{F}_{(7,534)}=\right.$ 4.59; $\mathrm{p}=0.000)$. Post hoc analyses showed that Emergency Health students scored significantly higher than both Pharmacy and Social Work students. Also students of Dietetics and Nutrition students gave significantly higher SPT scores than students enrolled in Pharmacy, Social Work and Radiography and Medical Imaging.

SPA scores varied significantly between the health science courses $\left(F_{(7,533)}=2.63 ; \mathrm{p}=0.011\right)$. Post hoc analyses showed that Emergency Health students scored significantly higher than Pharmacy students.

SSP scores varied significantly between courses $\left(\mathrm{F}_{(7,535)}=\right.$ $2.55 ; \mathrm{p}=0.014)$, however post hoc tests failed to show significant differences between any two of the health science courses on this subscale. SAP scores did not vary significantly between courses.

\section{DREEM scores by gender}

Total DREEM scores were significantly higher for females $(M=138.8 ; S D=17.2)$ than males $(M=132.3 ; S D=20.7)$, 
$\left(t_{(545)}=3.18 ; p=0.002\right)$, as were several subscales. A summary of mean subscale scores and indication of significant differences by gender is presented in Table 3.

Table 3. Mean (SD) subscale and total DREEM scores for Monash University health science students in $2008 / 9$ by gender $(\mathrm{N}=548)$

\begin{tabular}{|c|c|c|c|c|}
\hline Students' perception & Female & Male & $\mathrm{t}$ & $\mathrm{p}$ \\
\hline Students' perception of learning & $\begin{array}{l}33.4 \\
(4.8)\end{array}$ & $\begin{array}{l}31.2 \\
(6.7)\end{array}$ & 3.42 & 0.001 \\
\hline Students' perception of teachers & $\begin{array}{l}31.9 \\
(4.9)\end{array}$ & $\begin{array}{l}30.5 \\
(5.3)\end{array}$ & 2.73 & 0.007 \\
\hline Students' academic self-perception & $\begin{array}{l}21.3 \\
(3.7)\end{array}$ & $\begin{array}{l}20.8 \\
(4.5)\end{array}$ & 1.21 & 0.226 \\
\hline Students' perception of atmosphere & $\begin{array}{l}33.0 \\
(5.5)\end{array}$ & $\begin{array}{l}31.9 \\
(6.7)\end{array}$ & 1.70 & 0.091 \\
\hline Students' social self-perception & $\begin{array}{l}19.2 \\
(3.7)\end{array}$ & $\begin{array}{l}18.2 \\
(3.1)\end{array}$ & 2.64 & 0.009 \\
\hline Total DREEM scale score & $\begin{array}{l}138.8 \\
(17.2)\end{array}$ & $\begin{array}{l}132.3 \\
(20.7)\end{array}$ & 3.18 & 0.002 \\
\hline $\mathrm{n}$ & 421 & 127 & & \\
\hline
\end{tabular}

\section{DREEM scores by education background}

Total DREEM and SPA scores were significantly higher for those who did not enrol in their course directly after completing high school (e.g., students who had a gap year) than those who did. A comparison of subscale means is displayed in Table 4.

\section{DREEM scores by year of enrolment}

Significant differences were found between year-levels of enrolment for total DREEM score, $\mathrm{F}_{(3,531)}=3.13, \mathrm{p}=0.026$, as well as the SPT, SPL and SPA subscales.

Table 4. Mean (SD) subscale and total DREEM scores for Monash University health science students in $2008 / 9$ by study pathway $(\mathrm{N}=548)$

\begin{tabular}{lcccc}
\hline Students' perception & $\begin{array}{c}\text { Direct } \\
\text { from high } \\
\text { school }\end{array}$ & $\begin{array}{c}\text { Indirect } \\
\text { from high } \\
\text { school }\end{array}$ & $\mathrm{t}$ & $\mathrm{p}$ \\
\hline Students' perception of & 32.5 & 33.3 & 1.79 & 0.075 \\
learning & $(5.4)$ & $(5.3)$ & & \\
Students' perception of & 31.2 & 32.0 & 1.92 & 0.056 \\
teachers & $(4.8)$ & $(5.3)$ & & \\
Students' academic self- & 21.0 & 21.5 & 1.43 & 0.152 \\
perception & $(4.2)$ & $(3.5)$ & & \\
Students' perception of & 32.3 & 33.4 & 2.11 & 0.035 \\
atmosphere & $(6.0)$ & $(5.3)$ & & \\
Students' social self- & 19.0 & 18.9 & 0.19 & 0.846 \\
perception & $(3.6)$ & $(3.7)$ & & \\
Total DREEM scale score & 135.9 & 139.1 & 2.02 & 0.043 \\
\hline $\mathrm{n}$ & $(18.8)$ & $(17.4)$ & & \\
\hline
\end{tabular}

Pair-wise comparisons indicted that $2^{\text {nd }}$ year students gave significantly higher Total DREEM ratings than $4^{\text {th }}$ year students. Second year students also gave significantly higher SPL ratings than both $1^{\text {st }}$ year and $4^{\text {th }}$ year students and significantly higher SPA ratings than $4^{\text {th }}$ year students. 98
Subscale means, standard deviations and significant differences between year levels are presented in Table 5 .

\section{Discussion}

This study aimed to evaluate the education environment as perceived by students of a range of health science courses at a major Australian university. It also aimed to investigate whether the education environment or aspects of it are perceived more or less favourably among students from different health professions, year levels, educational backgrounds or genders.

Perception of academic learning environments for entire health science student group

Total DREEM scores were high across the study, indicating that students' perceptions of classroom learning environments were quite positive across the health science courses. The mean of 137.3 (68.7\%) fell well inside the range (101150 ) said to indicate a "more positive than negative" perception of environment. ${ }^{16,17}$ This was fairly consistent across the different aspects of the learning environments. As a percentage of the maximum possible score, mean scores ranged from $66 \%$ to $72 \%$ for each subscale. Admittedly, it should be conceded that the vast majority of past studies appear to have also yielded mean overall scores within this range. ${ }^{10}$ However, most published studies have yielded mean scores lower than the present study - anything from $45 \%$ to $65 \%$ of the maximum score..$^{10,13,15-17,21}$

A few studies have yielded higher total DREEM scores than the present study, ${ }^{10,12,20,22}$ which may reflect that these institutions are fairly innovative in terms of providing a student-centred approach to education. ${ }^{10}$ Indeed, the higher-than-average scores in the present study suggest that the environment is perceived positively by the students and also suggests that health science courses at Monash University are also student-centred. These are factors that are likely to have positive impact on the students' achievement, satisfaction and success. ${ }^{1,13,23}$

\section{Perception of academic learning environments by} health science discipline

The positive perception of the university learning environments was shared by students of all health science disciplines, indicated by total means ranging from 135.6 to 145.5 and subscale means between $60 \%$ and $80 \%$ of the maximum score. A few trends were also found between the different cohorts. Most notably, Emergency Health and Dietetics and Nutrition students appeared to view their learning environments more favourably than Pharmacy students, particularly in regard to their perception of the learning, teachers and atmosphere. Radiography and Medical Imaging and Social Work students also appeared to rate their teachers less favourably than did other student groups.

When addressing the differences in ratings noted between the courses, it is worth remembering that scores were 
fairly high across the study - even for the weakest course on the weakest subscale. Therefore, the results may indicate particular strengths within certain courses, rather than particular weaknesses within others. Further analyses to identify particularly strong items, and subsequent qualitative investigation of these areas, might enable key strengths to be identified within certain courses. These could then be replicated in the other health science courses at other institutions where practical.

\section{Perception of academic learning environments by gender}

Female health science students indicated a more positive perception of their environment than did males. While this trend was not statistically significant across all aspects of environment (SAP and SPA were not), there was a trend across the DREEM subscales generally, underscored by a significant difference overall. This is consistent with past studies involving students from the UK, ${ }^{9,17}$ which is a trend that was shown to be the opposite in the Middle East, ${ }^{10}$ the West Indies ${ }^{15}$ and Sri Lanka. ${ }^{16}$ This could reflect that the curriculum, staff and/or student cohort at Australian universities may have more similarities to those in the UK than in many other parts of the world.

With regard to the individual subscales, perception of learning was the area that showed greatest disparity between genders. Mean scores on this subscale were more than two points higher for females than males. This suggests that the female students perceived factors such as curriculum, structure, focus and goals more positively than their male counterparts. The extent to which this trend, and indeed the trend that females perceived their course environments more favourably overall, can be generalised to other institutions is not clear. On one hand, there is long-standing evidence that males and females typically exhibit different learning styles, ${ }^{24}$ which could partly explain differences in the way learning, and the environments generally, are perceived in the present study. On the other hand, another Australian study, which investigated the perceptions of mainly applied science students, found that males and females perceived their courses in an almost identical way. ${ }^{25}$

Perhaps the key difference with the health sciences is the higher proportion of females in the industry. That is, with more females than males being trained in health science professions in recent decades, ${ }^{26}$ and subsequently most likely delivering the majority of teaching in the classroom and/or clinical setting, it is possible there is an unconscious but natural leaning towards the learning needs of females. In other words, there may be a gender bias, whereby female students respond more favourably to female teachers. Such a theory might not be a too far-fetched, given past academic discourse about the existence of gender bias in student evaluations of teachers. ${ }^{27}$

Table 5. Mean (SD) subscale and total DREEM scores for Monash University health science students in $2008 / 9$ by year of enrolment $(N=548)$

\begin{tabular}{|c|c|c|c|c|c|c|c|}
\hline $\begin{array}{l}\text { Students' } \\
\text { perception }\end{array}$ & $1^{\text {st }}$ & $2^{\text {nd }}$ & $3^{\text {rd }}$ & $4^{\text {th }}$ & $\mathrm{F}$ & $p$ & $\begin{array}{c}\text { Tukey's } \\
<0.05\end{array}$ \\
\hline $\begin{array}{l}\text { Students' } \\
\text { perception of } \\
\text { learning }\end{array}$ & $\begin{array}{l}32.4 \\
(4.9)\end{array}$ & $\begin{array}{l}34.6 \\
(5.5)\end{array}$ & $\begin{array}{l}33.2 \\
(5.4)\end{array}$ & $\begin{array}{l}31.9 \\
(5.4)\end{array}$ & 5.84 & 0.001 & $\begin{array}{l}2^{\text {nd }}-1^{\text {st }} \\
2^{\text {nd }}-4^{\text {th }}\end{array}$ \\
\hline $\begin{array}{l}\text { Students' } \\
\text { perception of } \\
\text { teachers }\end{array}$ & $\begin{array}{l}32.1 \\
(5.3)\end{array}$ & $\begin{array}{l}31.7 \\
(4.6)\end{array}$ & $\begin{array}{l}32.0 \\
(4.9)\end{array}$ & $\begin{array}{l}30.6 \\
(5.7)\end{array}$ & 3.08 & 0.027 & \\
\hline $\begin{array}{l}\text { Students' } \\
\text { academic self- } \\
\text { perception }\end{array}$ & $\begin{array}{l}20.5 \\
(4.1)\end{array}$ & $\begin{array}{l}21.8 \\
(3.3)\end{array}$ & $\begin{array}{l}31.0 \\
(4.9)\end{array}$ & $\begin{array}{l}30.6 \\
(5.2)\end{array}$ & 2.26 & 0.081 & \\
\hline $\begin{array}{l}\text { Students' } \\
\text { perception of } \\
\text { atmosphere }\end{array}$ & $\begin{array}{l}32.3 \\
(5.8)\end{array}$ & $\begin{array}{l}34.2 \\
(4.3)\end{array}$ & $\begin{array}{l}32.7 \\
(6.4)\end{array}$ & $\begin{array}{l}32.3 \\
(5.9)\end{array}$ & 2.86 & 0.036 & $2^{\text {nd }}-4^{\text {th }}$ \\
\hline $\begin{array}{l}\text { Students' } \\
\text { social self- } \\
\text { perception }\end{array}$ & $\begin{array}{l}18.6 \\
(3.7)\end{array}$ & $\begin{array}{l}19.2 \\
(3.1)\end{array}$ & $\begin{array}{l}18.8 \\
(4.1)\end{array}$ & $\begin{array}{l}19.2 \\
(3.4)\end{array}$ & 0.91 & 0.438 & \\
\hline $\begin{array}{l}\text { Total DREEM } \\
\text { scale score }\end{array}$ & $\begin{array}{l}136.0 \\
(18.1)\end{array}$ & $\begin{array}{l}141.6 \\
(14.2)\end{array}$ & $\begin{array}{l}138.1 \\
(19.9)\end{array}$ & $\begin{array}{l}135.0 \\
(18.6)\end{array}$ & 3.13 & 0.026 & $2^{\text {nd }}-4^{\text {th }}$ \\
\hline$n$ & 121 & 101 & 150 & 176 & & & \\
\hline
\end{tabular}

Perception of academic learning environment by direct versus indirect high school graduates

Students that did not enrol in their tertiary course directly after completing high school (i.e. non-high school leavers) perceived their environments more positively than those who did. This trend was echoed across all DREEM subscales; however perception of atmosphere was the only aspect for which this difference was statistically significant.

There are a number of plausible explanations for why direct school leavers might perceive the health science undergraduate atmosphere less favourably. For instance, as non-direct high school graduates have a less straightforward pathway towards their course and/or they have already had related work experience, perhaps this sub-cohort is more determined to enrol in their course in the first place. They might then be more positive about the course and its atmosphere from the outset. Alternatively there are likely to be a range of generational differences between the two subcohorts, or variations in maturity levels, life experiences and previous education. Any of these factors could affect perception of course environment. Indeed the different characteristics, experiences and expectations of mature aged students have long been acknowledged. ${ }^{28}$ This has since been reflected in a variety of different perceptions made by mature versus younger applied science students in another Australian study. ${ }^{25}$

\section{Perception of academic learning environment by year of enrolment}

Perception of environment varied between year-level of enrolment, with second year students producing more positive DREEM results than fourth year students. While 
this trend was not significant for all subscales, it was consistently reflected by second year students topping each subscale and fourth year students generating the lowest ratings on most the DREEM subscales. The greatest difference between the two groups was in their perception of learning, for which second year students not only produced a mean rating 2.7 points higher than fourth years, they also significantly outscored first years. Perceptions of teachers and of atmosphere were also significantly superior for second year students over forth year students. Unlike previous studies ${ }^{13}$ this variation does not follow a consistent pattern year to year. Further analysis of each course separately, and perhaps individual items, is required to help explain these differences.

\section{Limitations and recommendations}

While this study provides a valuable insight into the course environment as perceived by health science students across eight disciplines in a contemporary curriculum setting, it would be valuable to conduct a similar study at another Australian university as well as international institutions. This would help establish the generalisability of the current findings to institutions with a similar curriculum.

Several other limitations should be acknowledged. Firstly, the number of participants varied considerably between courses and year levels. Secondly, individual items were not analysed and qualitative data was not collected in order to more deeply address specific problems or highlight strengths within the university or particular courses. However, there is nothing to suggest this cannot be carried out in the near future. Finally, for ethical reasons, convenience sampling was used to recruit participants. This may have inflated scores, as those who were present at the time of administration may have felt more positively towards their course than those who were absent (evidenced by the fact they were at class), or alternatively may have deflated the scores, as those with less satisfaction may have been keener to take part in order to voice their grievances. Admittedly, many of the previous studies that these results were compared to also used convenience sampling, however it is difficult to gauge what impact this has on scores for each study.

\section{Conclusions}

This study suggested students enrolled in contemporary Australian health science programs generally hold positive perceptions toward their course environment. This suggests a student-centred approach from the university and may lead to positive outcomes for the students. The extent to which these results can be generalised to other contemporary health science training providers depends on future, similar studies at other Australian and international institutions. Other findings in the present study, such as superior perceptions held by females and variations between year levels, are consistent with past research using medical students. These, as well as differences between courses and study pathway should be further investigated by analysis of specific items and sub-cohorts.

\section{Acknowledgements}

We wish to thank the Monash University health science students who gave their time to participate in the study and the reviewers for their time and constructive feedback.

\section{Conflict of Interest}

The authors declare that they have no conflict of interest.

\section{References}

1. Entwistle NJ, Ramsden P. Understanding student learning. London: Croom Helm; 1983.

2. Till H. Identifying the perceived weakness of a new curriculum by means of the Dundee Ready Education Environment Measure (DREEM) Inventory. Med Teach. 2004;26:39-45.

3. Genn JM. AMEE Medical Education Guide No 23 (Part 1): curriculum environment, climate, quality and change in medical education-a unifying perspective. Med Teach. 2001;23:337-44.

4. Salvatori P. Meaningful occupation for occupational therapy students: a student-centred curriculum. Occupational Therapy International. 1999;6:207-23.

5. Button D, Davies S. Experiences of encouraging student-centred learning within a wellness-orientated curriculum. Nurs Educ Today. 1991;16:407-12.

6. Health Professions Council of Australia Ltd. The allied health professional workforce in Australia: challenges and opportunities. [cited 2011 June]; Available from: http://www.ahpa.com.au/pdfs/submission_08.05.pdf.

7. McMeekan J. Physiotherapy education - what are the costs? Aust J Physiother. 2008;54:85-6.

8. Wray N, McCall L. 'They don't know much about us': educational reform impacts on students' learning in the clinical environment. Adv Health Sci Educ. 2009;14:665-76. 9. Roff S, McAleer S, Harden RM, Al-Qahtani M, Ahmed $\mathrm{AU}$, Deza $\mathrm{H}$, et al. Development and validation of the Dundee Ready Education Environment Measure (DREEM). Med Teach. 1997;19:295-9.

10. Roff S. The Dundee Ready Education Environment Measure (DREEM)-a generic instrument for measuring students' perceptions of undergraduate health professions curricula. Med Teach. 2005;27:322-5.

11. Denz-Penhey H, Murdoch C. A comparison between findings from the DREEM questionnaire and that from qualitative reviews. Med Teach. 2009;31:449-53.

12. Zamzuri AT, Ali AN, Roff S, McAleer S. Students' perceptions of the educational environment at dental training college, Malaysia. Malaysian Dent J. 2004;25:15-26. 
13. Till H. Climate studies: can students' perceptions of the ideal educational environment be of use for institutional planning and resource utilization? Med Teach. 2005;27:332227.

14. Pololi L, Price J. Validation and use of an instrument to measure the learning environment as perceived by medical students. Teach Learn Med. 2000;12:201-7.

15. Bassau B, Roff S, McAleer S, Roopnarinesingh S, Lisle JD, Teelucksingh S, et al. Students' perspectives on the educational environment, Faculty of Medical Sciences, Trinidad. Med Teach. 2003;25:522-6.

16. Jiffry MTT, McAleer S, Fernando S, Marasinghe RB. Using the DREEM questionnaire to gather baseline information on an evolving medical school in Sri Lanka. Med Teach. 2005;27:348-52.

17. Dunne F, McAleer S, Roff S. Assessment of the undergraduate medical environment in a large UK medical school. Health Educ J. 2006;65:149-58.

18. Roff S, McAleer S, Ifere OS, Bhattacharya S. A global diagnostic tool for measuring educational environment: comparing Nigeria and Nepal. Med Teach. 2001;23:378-82. 19. de Oliveria Filho GR, Vieira JE, Schonhorst L. Psychometric properties of the Dundee Ready Education Environment Measure (DREEM) applied to medical residents. Med Teach. 2005;4:343-7.

20. Varma R, Tiyagi E, Gupta JK. Determining the quality of educational climate across multiple undergraduate teaching sites using the DREEM inventory. BMC Med
Educ. 2005;5:8.

21. Al-Hazimi A, Zaini R, Al-Hyiani A, Hassan N, Gunaid A, Ponnamperuma G, et al. Educational environment in traditional and innovative medical schools: a study in four undergraduate medical schools. Educ Health. 2004;17:192203.

22. Miles S, Leinster SJ. Comparing staff and student perception of the student experience at a new medical school. Med Teach. 2009;31:539-46.

23. Mayya S, Roff S. Students' perceptions of educational environment: a comparison of academic achievers and under-achievers at Kasturba Medical College, India. Educ Health. 2004;17:280-91.

24. Philbin M, Meier E, Huffman S, Boverie P. A survey of gender and learning styles. Sex Roles. 1995;32:485-94.

25. Nair CS. Changing learning environments for quality tertiary classes. In: Goody A, Ingram DD, editors. Spheres of influence: ventures and visions in educational development. Perth: University of Western Australia; 2002.

26. Booth A, Kee HJ. The university gap in Australia: a long run perspective. Canberra: Australian National University; 2009.

27. Centra JA, Gaubatz NB. Is there gender bias in student evaluation of teaching? J High Educ. 2000(71):17-33.

28. Phillips CJ. Full-time mature students in higher education: a survey of their characteristics, experiences and expectations. Brit Educ Res J. 1986;12:289-308. 